\title{
Heterologous primer transferability and access to microsatellite loci polymorphism in "somnus" passion fruit tree (Passiflora setacea DC)
}

\author{
Douglas de Almeida Pereira ${ }^{1 *}$ \\ Fernanda Amato Gaiotto ${ }^{2}$ \\ Ronan Xavier Corrêa ${ }^{2}$ \\ Antonio Carlos de Oliveira ${ }^{1}$ \\ ${ }^{1}$ Universidade Estadual do Sudoeste da Bahia, Departamento de Ciências Naturais \\ Estrada do Bem Querer, km 04, CEP 45083-900, Vitória da Conquista - BA, Brasil \\ ${ }^{2}$ Universidade Estadual de Santa Cruz, Departamento de Ciências Biológicas \\ Rodovia Jorge Amado, km 16, Bairro Salobrinho, CEP 45662-900, Ilhéus - BA, Brasil \\ * Autor para correspondência \\ douglasbiologo@ig.com.br
}

Submetido em 02/07/2014

Aceito para publicação em 09/04/2015

\section{Resumo}

Transferibilidade de primers heterólogos e acesso ao polimorfismo de loci microssatélites em maracujazeiro-do-sono (Passiflora setacea DC). Pares de primers que acessam loci microssatélites, inicialmente construídos a partir do genoma de Passiflora edulis Sims flavicarpa e P. alata, foram testados quanto à sua capacidade de acessar loci microssatélites em indivíduos de maracujazeiro-do-sono (P. setacea). Sete dos trinta e um pares de primers testados foram capazes de acessar polimorfismo de DNA no genoma dessa espécie silvestre de Passiflora, ao avaliar seis populações naturais, localizadas em área de transição entre os biomas Caatinga e Cerrado, no estado da Bahia. O número de alelos/loci foi baixo, oscilando de um a quatro. A heterozigosidade média observada por locus em todas as populações variou de 0,13 a 0,40 . Houve transferência dos pares de primers microssatélites heterólogos do gênero Passiflora para maracujazeiro-do-sono, constituindo um novo conjunto de primers que acessam locus codominante aleatório nessa espécie, útil para fins de conservação e pré-melhoramento do maracujazeiro-do-sono.

Palavras-chave: Diversidade genética; Maracujazeiro-do-sono; Simple sequence repeat; Transferibilidade

\section{Abstract}

Primer pairs that access microsatellite loci, initially constructed through the genome of Passiflora edulis Sims flavicarpa and P. alata, were tested concerning their ability to access microsatellite loci in "somnus" passion fruit tree (P. setacea) individuals. Seven out of the thirty one primer pairs tested were able to access DNA polymorphism in the genome of this wild Passiflora species, by evaluating six natural populations, located in a transition area between the biomes Caatinga and Cerrado, in the state of Bahia, Brazil. The number of alleles/ loci was small, oscillating from 1 to 4 . The average heterozygosity observed per locus in all populations ranged from 0.13 to 0.40 . There was transference of heterologous microsatellite primer pairs from the Passiflora genus to "somnus" passion fruit tree, constituting a new set of primers that access random co-dominant locus in this species, useful for conservationist purposes and pre-improvement of "somnus" passion fruit tree.

Key words: Genetic diversity; Simple sequence repeat; 'Somnus' passion fruit tree; Transferability 


\section{Introduction}

Various plant habitats have been destroyed due to increased human activity, such as the excessive exploitation of natural resources, large-scale construction projects, and environmental pollution. Habitat destruction by fragmentation and reduction of naturally occurring areas has turned large populations into small and isolated populations. A reduced population size can lead to decreased genetic variability within it, with a consequent reduction in the potential for evolution (YOUNG et al., 1996; FRANKHAM et al., 2002). Smaller, isolated populations can lose their genetic diversity due to accelerated endogamy and genetic oscillation, therefore, individual reproductive viability and ability within such populations can be compromised, thus their ability to adapt to changes can be decreased as well, leading these populations to extinction (JEONG et al., 2010).

So, maintaining genetic variability is paramount to the species' survival, especially wild Passiflora species, which have not been given the needed attention. 'Somnus' passion fruit tree - P. setacea (Passifloraceae), for instance, is a Brazilian native species known for its resilience to pathogens and the much appreciated sweetness and flavor of its fruit (BRAGA et al., 2006).

Scholars point out that some Brazilian native Passiflora species have a great potential as contributors to the genetic improvement of commercial passion fruit tree crops, because they have a pool of genes related with resistance to diseases and some pests, combined with other relevant features, such as longevity, self-compatibility, greater adaptation to adverse weather conditions, longer flowering period, shorter androgynophore that makes pollination by small insects easy, and a higher concentration of chemicals (JUNQUEIRA et al., 2005; MELETTI et al., 2005).

Little is known about the diversity and genetic structure of "somnus" passion fruit tree. Understanding the effects of spatial isolation and the genetic diversity and gene dispersion level is crucial to establish conservation strategies, as well as in situ and ex situ preimprovement of this significant species. For this purpose, access to microsatellite or simple sequence repeat (SSR) loci polymorphism is a very useful information tool, since the alleles of these loci have advantages such as co-dominance and multiple allelism (OLIVEIRA, 2006), and they are extensively used to access the genetic structure of populations. Among the disadvantages of the SSR technique there is the high cost and time spent developing the primer pairs, along with the low frequency of microsatellite loci in plants (POWELL et al., 1996). For this reason, cross-amplification becomes an interesting alternative to reduce costs related to SSR polymorphism access in species that do not have commercial appeal, yet, such as 'somnus' passion fruit tree.

Faced with the need to have co-dominant primer pairs to provide some support to conservation work related to "somnus" passion fruit tree germoplasm and the destination of superior genotypes to preimprovement of this species, this study aimed to address the transferability of microsatellite primer pairs to this species from primer sets previously developed for commercial Passiflora species. The primer pairs transferred came from six 'somnus' passion fruit tree populations.

\section{Material and Methods}

For the genetic analysis, leaves were collected from 120 plants in six naturally occurring populations of this species, Belo Campo (BC), Piripá (PP), Tremedal (TR), Cândido Sales (CS), Condeúba (CD), and Jacaraci (JA), (6 populations x 20 individuals/population), located in the GeoEnvironmental Units $\mathrm{C} 5$ and $\mathrm{C} 7$, according to the notation by the Zoneamento Agroecológico do Nordeste (ZANE), the Northeast Agro-Ecological Zoning (SILVA et al., 2000). Leaf tissue was stored in Kraft paper bags and transported on ice in a polystyrene box for better conservation, until it was kept stored at $-20^{\circ} \mathrm{C}$ in the Molecular Markers Laboratory of the State University of Santa Cruz (UESC), in the state of Bahia, Brazil; $400 \mathrm{mg}$ of young leaves were used for extracting total genomic DNA. To do this, we used the CTAB protocol described by Doyle and Doyle (1990). DNA quality was confirmed by electrophoresis in $0.8 \%$ agar gel and the concentration was determined by ImageQuant 400 spectrophotometer. DNA stock solutions were diluted in 
sterilized Milli-Q water, in order to obtain $10 \mathrm{ng} / \mu \mathrm{L}$ as working concentrations of total genomic DNA.

Twenty five microsatellite primer pairs designed for Passiflora edulis (OLIVEIRA, 2006) and six primer pairs designed for $P$. alata (PÁDUA et al., 2005) were tested for their transferability to access SSR polymorphism in "somnus" passion fruit tree individuals. Each primer pair was investigated in Polymerase Chain Reaction (PCR) at 6 increasing annealing temperatures (between 50 and $56^{\circ} \mathrm{C}$ ) for DNA samples of 4 individuals $\mathrm{x} 3$ locations. The reactions were carried out in Apllied ${ }^{\circledR}$ thermal cycler with a final volume of $13 \mu \mathrm{L}-30 \mathrm{ng}$ of genomic DNA, buffer of PCR 10X, $1.5 \mathrm{mM}$ of $\mathrm{MgCl} 2,0.2 \mathrm{mM}$ of each dNTP, $0.3 \mathrm{mM}$ of each primer, 1U/Taq DNA Polymerase - submitted to initial DNA denaturation at $94^{\circ} \mathrm{C}$ for $5 \mathrm{~min}$, followed by 30 cycles of $(i)$ denaturation at $94^{\circ} \mathrm{C}$ for $1 \mathrm{~min}$; (ii) primer annealing (see Table 1) $72^{\circ} \mathrm{C}$ for $1 \mathrm{~min}$. After the 30 cycles, there was an addition phase of final extension at $72^{\circ} \mathrm{C}$ for 7 min to conclude the synthesis of amplicons. Loci annealing temperature $\left(\mathrm{T}_{\mathrm{a}}{ }^{\circ} \mathrm{C}\right)$ was adjusted, being moderately decreased until greater amplification intensity was achieved. Based on a pre-established visual criterion, successful amplification consisted in 1 or 2 bands around the expected allele. After determining the annealing temperature of choice for each microsatellite primer pair, the alleles of loci that showed clear and robust amplification of bands in 2\% agar gel under electrophoresis for 1.30 hour at $110 \mathrm{~V}$ were selected for polymorphism analysis in $6 \%$ polyacrylamide gel ( $2 \mathrm{~h}$ at $60 \mathrm{~W}$ ), stained with silver nitrate, according to Creste et al. (2001). Photodocumentation took place under white light, in order to verify the electrophoretic profile. DNA ladder $(10 p b)$ (Invitrogen $\left.{ }^{\circledR}\right)$ was used to estimate the amplicons size.

Polymorphic loci were characterized for "somnus" passion fruit tree populations by considering the number of alleles per locus (na), as well as the observed (Ho) and expected (He) heterozygosity in each locus. Genetic distance and genetic divergence among populations (FST) were investigated through the software GenAlEx 6.1 (PEAKALL; SMOUSE, 2006). The dendrogram was constructed having Nei's genetic distance as a basis (NEI, 1972), using Unweighted Pair Group Method with Arithmetic Mean (UPGMA) as the group method, resorting to help from the GENES program (CRUZ, 1998).

\section{Results and Discussion}

Among the 31 primer pairs tested, 21 (67.74\%) showed satisfactory cross-amplification results in "somnus" passion fruit trees. The primer pairs tested provided access to over half of the loci tested in the species under study, something which enabled us to conclude that the areas bordering microsatellites in species of the genus Passiflora spp. are reasonably wellpreserved and enough to allow cross-amplification. In addition, in their own way, out of the 21 loci transferred, $7(22.58 \%)$ were polymorphic in the test with 6 natural populations of the species (Table 1). This figure may be regarded as relatively high when compared to the study conducted by Zucchi et al. (2002), where only 2\% of the primer pairs showing cross-amplification from Eucalyptus to E. dysenteria were polymorphic.

According to Peakall et al. (1998), crossamplification studies involving SSR loci alleles within the same plant genus have shown that the proportion of polymorphic loci ranged from $20 \%$ to $100 \%$, therefore, the figure achieved in this research falls within this scope. Heterologous primer pairs resulted in an easy SSR polymorphism access, in $6 \%$ polyacrylamide gel with well-defined alleles. The annealing temperature of the transferred primer pairs ranged from $50^{\circ} \mathrm{C}$ to $55^{\circ} \mathrm{C}$ and the variation in amplitude of SSR amplicons size, considering the loci as a whole, was between 130 and $270 p b$ (Table 1).

Many authors recognize that cross-amplification success is related to preserving the sequence in the regions bordering microsatellites (KIJAS et al., 1995; BYRNE et al., 1996; DAYANANDAN et al., 1997). Preserving the sequence depends on the evolutionary relation between the species of origin (for which the primer pair is designed) and the target species (for which the cross-amplification is tested). The more diverse the taxon, the less successful the cross-amplification will be. Data from this research allow us to infer that "somnus" passion fruit tree presents a certain genomic homology with the species P.edulis and P. alata. 
TABLE 1: Microsatellite locus features in 6 naturally occurring populations of "somnus" passion fruit tree (P. setacea). (A) Number of alleles per locus; (Ho) observed heterozygosity; (He) expected heterozygosity; $\mathrm{Ta}{ }^{\circ} \mathrm{C}=$ Annealing temperature.

\begin{tabular}{|c|c|c|c|c|c|c|c|c|c|c|c|c|c|c|c|c|c|c|c|c|c|}
\hline \multirow{2}{*}{ Locus } & \multirow{2}{*}{$\begin{array}{l}\text { Expected } \\
\text { allele }(p b)\end{array}$} & \multirow{2}{*}{$\begin{array}{c}\text { Amplicon } \\
\text { size }(p b)\end{array}$} & \multirow{2}{*}{$\mathrm{Ta}^{\circ} \mathrm{C}$} & \multicolumn{6}{|c|}{ A } & \multicolumn{6}{|c|}{ Но } & \multicolumn{6}{|c|}{$\mathrm{He}$} \\
\hline & & & & BC & PP & TR & CS & CD & JA & BC & PP & TR & CS & CD & JA & BC & PP & TR & CS & CD & JA \\
\hline PE 08 & 282 & $230-250$ & 53 & 3 & 3 & 3 & 3 & 3 & 2 & 0.05 & 0.23 & 0.60 & 0.78 & 0.10 & 0.11 & 0.14 & 0.26 & 0.53 & 0.55 & 0.44 & 0.44 \\
\hline PE09 & 268 & $260-270$ & 50 & 2 & 3 & 3 & 1 & 3 & 3 & 0.10 & 0.50 & 0.15 & 0.00 & 0.26 & 0.45 & 0.18 & 0.51 & 0.26 & 0.00 & 0.56 & 0.55 \\
\hline PE15 & 204 & $190-210$ & 51 & 4 & 3 & 3 & 2 & 3 & 4 & 0.25 & 1.00 & 0.35 & 0.45 & 0.45 & 0.45 & 0.30 & 0.56 & 0.30 & 0.35 & 0.44 & 0.38 \\
\hline PE25 & 246 & $200-210$ & 55 & 2 & 2 & 3 & 2 & 3 & 2 & 0.16 & 0.47 & 0.63 & 1.00 & 1.00 & 0.87 & 0.14 & 0.46 & 0.47 & 0.50 & 0.58 & 0.49 \\
\hline PE27 & 139 & $130-150$ & 55 & 3 & 2 & 3 & 1 & 2 & 1 & 0.35 & 0.06 & 0.31 & 0.00 & 0.05 & 0.00 & 0.30 & 0.05 & 0.27 & 0.00 & 0.05 & 0.00 \\
\hline PE43 & 241 & $215-235$ & 55 & 1 & 3 & 2 & 1 & 2 & 2 & 0.00 & 0.20 & 0.10 & 0.00 & 0.20 & 0.60 & 0.00 & 0.30 & 0.09 & 0.00 & 0.25 & 0.45 \\
\hline $\mathrm{A} 08 \mathrm{FP} 1$ & 200 & $190-205$ & 55 & 1 & 1 & 1 & 1 & 2 & 2 & 0.00 & 0.00 & 0.00 & 0.00 & 0.11 & 0.35 & 0.00 & 0.00 & 0.00 & 0.00 & 0.10 & 0.29 \\
\hline Average & & & & 2.3 & 2.4 & 2.6 & 1.6 & 2.6 & 2.3 & 0.13 & 0.35 & 0.31 & 0.32 & 0.31 & 0.40 & 0.15 & 0.31 & 0.27 & 0.20 & 0.35 & 0.37 \\
\hline
\end{tabular}

$\mathrm{BC}=$ Belo Campo. $\mathrm{TR}=$ Tremedal. $\mathrm{CS}=$ Cândido Sales. $\mathrm{PP}=$ Piripá. $\mathrm{CD}=$ Condeúba. $\mathrm{JA}=$ Jacaraci.

Many studies involving tropical and temperate species have reported the utility of heterologous primers to access SSR loci polymorphism in closely related taxa (BRAGA et al., 2007; LEMES et al., 2007; FERES et al., 2009; NAZARENO et al., 2009; WÜNSCH, 2009; LEE et al., 2011).

Non-polymorphic loci (PE01, PE73, PE106, PE108, and PE20) cannot be omitted in further studies. They may be able to show polymorphism when tested by using other P. setacea material from different locations. For instance, PA08FP1 exhibited monomorphic amplicons when individuals from populations BC, PP, TR, and CS were evaluated, although the same locus showed to be polymorphic for populations $\mathrm{CD}$ and JA.

In order to test the usefulness of transferable and polymorphic SSR primer pairs for ecologic studies and genetic diversity of "somnus" passion fruit tree, a set of 7 pairs of polymorphic primers that access loci PE08, PE09, PE15, PE25, PE27, PE43, and PA08FP1 was selected to access genetic diversity parameters in 120 individuals distributed through 6 naturally occurring populations. The na observed were $2.3 ; 2.4 ; 2.6 ; 1.6 ; 2.6$, and 2.3 for $\mathrm{BC}, \mathrm{PP}, \mathrm{TR}, \mathrm{CS}, \mathrm{CD}$, and JA populations, respectively (Table 1).
Regarding the successful transferability obtained in this work, a relatively low level of multiple allelism was observed in the 7 polymorphic heterologous loci (mean number of 2.3 alleles per locus) when compared to studies carried out with other species, such as Zucchi et al. (2002), using a mean number of 10.4 alleles per locus.

In Silva (2010), which evaluated the transferability of SSR primers developed in P. edulis for wild passiflora species of the Germoplasm Bank of UESC. In this study, polymorphic loci were detected through few alleles, most of them were monomorphic (the largest amount of alleles found was 5, for P. alata.). Caution must be taken when analyzing low allele values for the transferability of SSR primer pairs, since using access to microsatellite loci designed for the species themselves also showed low mean allele values, such as in yellow passion fruit tree (5.3 alleles/locus) (OLIVEIRA et al., 2005) and in the sweet passion fruit tree (3.14 alleles/locus) (PÁDUA et al., 2005).

The Ho values distributed in the 6 populations ranged from 0 to 1 , with a mean value of 0.30 . Variation in He was between 0 and 0.58 , with a mean value of 0.27 (Table 1). For most of the populations evaluated, the mean Ho was higher than the expected He. There 
were deviations from Hardy-Weinberg equilibrium for most loci $(p<0.01)$, with the exception of locus PE06.

In the dendrogram (Figure 1), the populations were arranged into two distinct groups; the least Nei genetic distance was between populations TR and CS (0.02) and the longer genetic distance was between $\mathrm{BC}$ and $\mathrm{CD}$ (0.36). The genetic differentiation between populations was high and significant $(\mathrm{FST}=0.27 ; p<0.01)$.

In a study addressing the transferability of pairs of microsatellite primers for white ipe tree, Feres et al. (2009) detected significant FST values (0.15), evidencing that naturally occurring populations of 'somnus' passion fruit trees are genetically structured.

Thus, transferability of the 7 primer pairs that access polymorphic SSR loci constitutes an extremely useful tool for genetic and population studies, especially for studies aimed at the preservation and pre-improvement of "somnus" passion fruit tree. The results found in this research indicate that cross-amplification for other species of this genus is also possible.

FIGURE 1: UPGMA grouping of 6 "somnus" passion fruit tree populations ( $P$. setacea) based on genetic similarity using 7 pairs of microsatellite primers. $\mathrm{BC}=$ Belo Campo; $\mathrm{TR}=$ Tremedal; $\mathrm{CS}=$ Cândido Sales; $\mathrm{PP}=$ Piripá; $\mathrm{CD}=$ Condeúba; JA = Jacaraci.

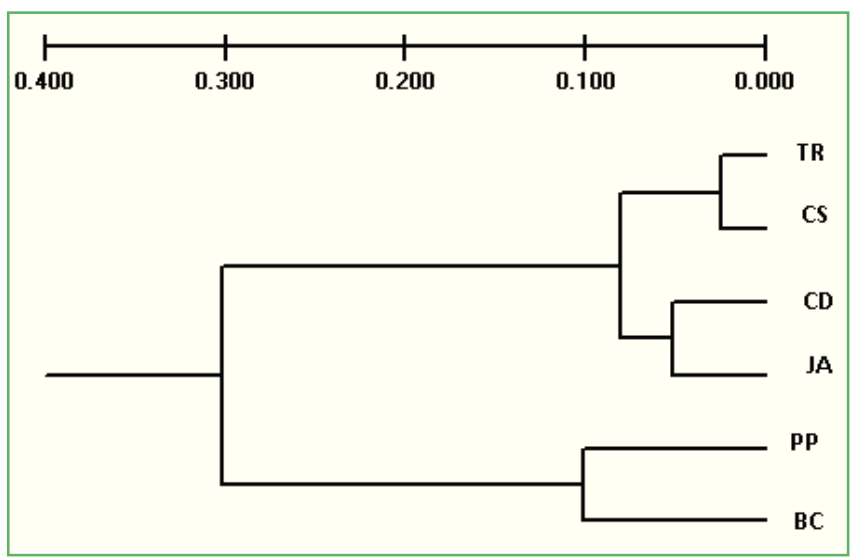

\section{Acknowledgements}

The authors would like to thank the Research Support Foundation of the State of Bahia (FAPESB), for awarding the grant, and the State University of Santa Cruz (UESC), for the financial support provided.

\section{References}

BRAGA, A. C.; REIS, A. M. M.; LEOI, L. T.; PEREIRA, R. W.; COLLEVATTI, R. G. Development and characterization of microsatellite markers for the tropical tree species Tabebuia aurea (Bignoniaceae). Molecular Ecology Notes, Weinheim, v. 7, n. 1, p. 53-56, 2007.

BRAGA, M. F.; JUNQUEIRA, N. T. V.; FALEIRO, F. G.; AGOSTINI-COSTA, T. S.; BERNACCI, L. C. Maracujá-doCerrado. In: VIEIRA, R. F.; AGOSTINI-COSTA, T. S.; SILVA, D. B.; FERREIRA, F. R.; SANO, S. M. (Ed). Frutas nativas da região Centro-Oeste. 1 ed. Brasília: EMBRAPA, 2006. p. 216233.

BYRNE, M.; MARQUEZ-GARCIA, M. I.; UREN, T.; SMITH, D. S.; MORAN, G. F. Conservation and genetic diversity of microsatellite loci in the genus Eucalipytus. Australian Journal of Botany, Collingwood, v. 44, n. 3, p. 331-341, 1996.

CRESTE, S.; TULMANN-NETO, A.; FIGUEIRA, A. Detection of single sequence repeat polymorphisms in denaturing polyacrylamide sequencing gels by silver staining. Plant Molecular Biology Reporter, New York, v. 19, n. 1, p. 299-306, 2001.

CRUZ, C. D. Programa GENES: Aplicativo computacional em estatística aplicada à genética (GENES - Software for Experimental Statistics in Genetics). Genetics and Molecular Biology, Ribeirão Preto, v. 21, n. 1, 1998. Doi: <http://dx.doi.org/10.1590/S141547571998000100022>.

DAYANANDAN, S.; BAWA, K.; KESSELI, R. Conservation of microsatellites among tropical trees (Leguminosae). American Journal of Botany, Columbus, v. 84, n. 12, p. 1658-1663, 1997.

DOYLE, J. J.; DOYLE, J. L. Isolation of plant DNA from fresh tissue. Focus, Gaithesburg, v. 12, n. 1, p. 13-15, 1990.

FERES, J. M.; MARTINEZ, M. L. L.; MARTINEZ, C. A.; MESTRINER, M. A.; ALZATE-MARIN, A. L. Transferability and characterization of nine microsatellite markers for the tropical tree species Tabebuia roseoalba. Molecular Ecology Resource, Vancouver, v. 9, n. 1, p. 434-437, 2009.

FRANKHAM, R.; BALLOU, J. D.; BRISCOE, D. A. Introduction to conservation genetics. New York: Cambridge University Press, 2002. 607 p.

JEONG, J. H.; KIM, E. H.; GUO, W.; YOO, K. O.; JO, D. G.; KIM, Z. S. Genetic diversity and structure of endangered species Megaleranthis saniculifolia in Korea as revealed by allozyme and ISSR markers. Plant Systematics and Evolution, Heidelberg, v. 289, n. 1, p. 67-76, 2010.

JUNQUEIRA, N. T. V.; BRAGA, M. F.; FALEIRO, F. G.; PEIXOTO, J. R. Potencial de espécies silvestres de maracujazeiro como fonte de resistência a doenças. In: FALEIRO, F. G.; JUNQUEIRA, N. T. V.; BRAGA, M. F. (Ed.) Maracujá: germoplasma e melhoramento genético. 1. ed. Planaltina: Embrapa Cerrados, 2005. p. 79-108.

KIJAS, J.; FOWLER, J. C. S.; THOMAS, M. R. An evaluation of sequence tagged microsatellite site markers for genetic analysis within citrus and related species. Genome, Saskatoon, v. 38, n. 2, p. 349-355, 1995.

LEE, G. A.; KWON, S. J.; PARK, Y. J.; LEE, M. C. Crossamplification of SSR markers developed from Allium sativum to other Allium species. Scientia Horticulturae, Amsterdam, v. 128, n. 4, p. 401-407, 2011. 
LEMES, M. R.; MARTINIANO, M. T.; REIS, V. M.; FARIA, C. Cross-amplification and characterization of microsatellite loci for three species of Theobroma (Sterculiaceae) from the Brazilian Amazon. Genetics Resource and Crop Evolution, Dordrecht, v. 54, n. 8, p. 1653-1657, 2007.

MELETTI, L. M. M.; SOARES-SCOT, M. D.; BERNACCI, L. C.; PASSOS, I. R. S. Melhoramento genético do maracujá: passado e futuro In: FALEIRO, F. G.; JUNQUEIRA, N. T. V.; BRAGA, M. F. (Ed.). Maracujá: germoplasma e melhoramento genético. 1. ed. Planaltina: Embrapa Cerrados, 2005. p. 55-78.

NAZARENO, A. G.; PEREIRA, R. A. S.; FERES, J. M.; MESTRINER, M. A.; ALZATE-MARIN, A. L. Transferability and characterization of microsatellite markers in two Neotropical Ficus species. Genetics and Molecular Biology, Ribeirão Preto, v. 32, n. 3, p. 568-571, 2009.

NEI, M. Genetic distance between populations. The American Naturalist, Chicago, v. 106, n. 949, p. 283-292, 1972.

OLIVEIRA, E. J. Desenvolvimento e uso de marcadores microssatélites para construção e integração de mapas genéticos de maracujá-amarelo (Passiflora edulis Sims f. flavicarpa Deg.). 2006. 153 f. Tese (Doutorado em Agronomia) - Universidade de São Paulo, Piracicaba. 2006.

OLIVEIRA, E. J.; PÁDUA, J. G.; ZUCCHI, M. I.; CAMARGO, L. E. A.; FUNGARO, M. H. P.; VIEIRA, M. L. C. Development and characterization of microsatellite markers from the yellow passion fruit (Passiflora edulis f. flavicarpa). Molecular Ecology Notes, Weinheim, v. 5, n. 2, p. 331-333, 2005.

PÁDUA, J. G.; OLIVEIRA, E. J.; ZUCCHI, M. I.; OLIVEIRA, Z. C. X. Isolation and characterization of microsatellite markers from the sweet passion fruit (Passiflora alata Curtis: Passifloraceae). Molecular Ecology Notes, Weinheim, v. 5, n. 4, p. 863-865, 2005.
PEAKALL, R.; GILMORE, S.; KEYS, W.; MORGANTE, M. Cross-species amplification of soybean (Glycine max) simple sequence repeat (SSRs) within the genus and other legume genera: implications for the transferability of SSRs in plants. Molecular Biology and Evolution, Oxford, v. 15, n. 10, p. 1275-1287, 1998.

PEAKALL, R.; SMOUSE, P. E. GENALEX 6: genetic analysis in Excel. Population genetic software for teaching and research. Molecular Ecology Notes, Weinheim, v. 6, n. 1, p. 288-295, 2006. POWELL, W.; MORGANTE, M.; ANDRE, C.; HANAFEY, M. The comparison of RFLP, RAPD, AFLP and SSR (microsatellite) markers for germplasm analysis. Molecular Breeding, Dordrecht, v. 2, n. 3, p. 225-238, 1996.

SILVA, A. A. S. Diversidade genética de passifloras silvestres do banco ativo de germoplasma da UESC utilizando marcadores microssatélites. 2010. 81 f. Dissertação (Mestrado em Genética) Universidade Estadual de Santa Cruz, Ilhéus. 2010.

SILVA, F. B. R.; SANTOS, J. C. P.; SOUZA NETO, N. C.; SILVA, A. B. Zoneamento agroecológico do Nordeste do Brasil: diagnóstico e prognóstico. Recife: Embrapa Solos - Escritório Regional de Pesquisa e Desenvolvimento Nordeste-ERP/NE: Petrolina: Embrapa Semi-Árido, 2000. CD. (Embrapa Solos. Documentos, 14).

WÜNSCH, A. Cross-transferable polymorphic SSR loci in Prunus species. Scientia Horticulturae, Amsterdam, v. 120, n. 3, p. 348$352,2009$.

YOUNG, A.; BOYLE, T.; BROWN, T. The population genetic consequences of habitat fragmentation for plant. Trends in Ecology and Evolution, Cambridge, v. 11, n. 10, p. 413-418, 1996.

ZUCCHI, M. I.; BRONDANI, R. P. V.; PINHEIRO, J. B.; BRONDANI, C. Transferability of microsatellite markers from Eucalyptus spp. to Eugenia dysenterica (Myrtaceae family). Molecular Ecology Notes, Weinheim, v. 2, n. 4, p. 512-513, 2002. 